\title{
Cellular Response to Renal Hypoxia Is Different in Adolescent and Infant Rats
}

\author{
SHINSUKE ADACHI, SERGEY ZELENIN, YASUTAKA MATSUO, AND ULLA HOLTBÄCK
}

Department of Woman and Child Health, Karolinska Institutet, S-171 76 Stockholm, Sweden [S.A., S.Z., Y.M., U.H.]; and Department of Pediatrics, Kyoto Prefectural University of Medicine, 602-8566 Kyoto, Japan [S.A., Y.M.]

\begin{abstract}
Immature renal tubules are more tolerant to ischemia than mature renal tubules. Here we compared the developmental pattern for some cellular responses evoked by hypoxia and reoxygenation in renal proximal tubules from 10- and 40-day-old rats. Redistribution of $\mathrm{Na}^{+}-\mathrm{K}^{+}$-ATPase from the plasma membrane was studied by confocal microscopy techniques in primary cultured renal proximal tubular cells. The developmental expression of $\mathrm{Na}^{+}-\mathrm{K}^{+}$-ATPase, $\mu$-calpain and heme oxygenase- 1 was measured by RT-PCR techniques in rat renal cortex. In response to hypoxia $\mathrm{Na}^{+}-\mathrm{K}^{+}$-ATPase redistribution from the plasma membrane was almost 2-fold increased in cells isolated from mature kidneys compared with cells isolated from immature kidneys. Reoxygenation resulted in a complete reestablishment of $\mathrm{Na}^{+}-\mathrm{K}^{+}$-ATPase in the plasma membrane in the immature but not in the mature cells. The dissociation of $\mathrm{Na}^{+}-\mathrm{K}^{+}$-ATPase from the plasma membrane was associated with a reduced activity and a reduced expression of $\mathrm{Na}^{+}-\mathrm{K}^{+}$-ATPase in the mature but not in the immature tubular cells. The expression of
\end{abstract}

\section{ABSTRACT}

$\mu$-calpain, a factor shown to induce ischemic injury to proximal tubular cells, was significantly lower in the immature compared with the mature kidney, whereas the expression of heme oxygenase-1, a factor shown to protect from renal ischemic injury, was significantly higher in the immature kidney. The results help to explain the increased tolerance of the immature kidney to injury caused by ischemia and reperfusion. (Pediatr Res 55: 485-491, 2004)

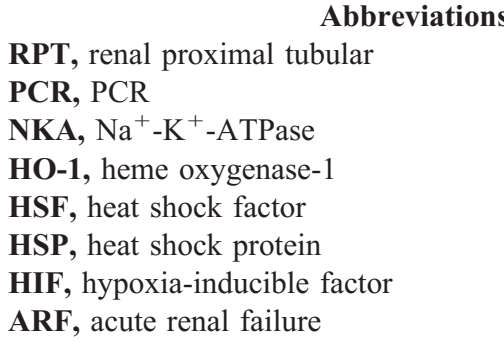

ciation and redistribution of $\mathrm{Na}^{+}-\mathrm{K}^{+}$-ATPase from the basolateral plasma membrane, increased intracellular $\mathrm{Ca}^{2+}$ level and subsequent activation of $\mathrm{Ca}^{2+}$-activated proteases, e.g. calpain and oxidative stress. The present study was performed to analyze the developmental pattern of these cellular responses to hypoxia and reoxygenation, in renal proximal tubules, the part of the nephron less tolerant of hypoxia.

Approximately $70 \%$ of renal oxygen consumption is related to $\mathrm{Na}^{+}-\mathrm{K}^{+}$-ATPase that uses it for vectorial transport of sodium, water, and other solutes across the renal tubular epithelial cell. One well-known event during renal ischemia is the dissociation of proximal tubular $\mathrm{Na}^{+}-\mathrm{K}^{+}$-ATPase from its cytoskeletal anchorage, followed by a redistribution of $\mathrm{Na}^{+}$$\mathrm{K}^{+}$-ATPase from the basolateral plasma membrane $(6,7,8)$. The transient loss of $\mathrm{Na}^{+}-\mathrm{K}^{+}$-ATPase from its basolateral localization explains the partially reversible clinical sequelae such as renal sodium, glucose, amino acid and water loss. We examined the spatial distribution of $\mathrm{Na}^{+}-\mathrm{K}^{+}$-ATPase by confocal microscopy techniques in primary cultures of renal proximal tubular (RPT) cells from 10- and 40-day-old rats. The
Received August 27, 2002; accepted February 27, 2003.

Correspondence: Ulla Holtbäck, M.D., Ph.D., Astrid Lindgren Children's Hospital S-171 76 Stockholm, Sweden; e-mail: ulla.holtback@ks.se

Supported by Riksbankens Jubileumsfond, Sweden, and Free Masons in Stockholm; Foundation for Children's Welfare, Sweden.

DOI: 10.1203/01.PDR.0000106805.54926.2C 
results suggest that $\mathrm{Na}^{+}-\mathrm{K}^{+}$-ATPase remained at the plasma membrane to a greater extent in immature compared with mature tubular cells in response to hypoxia.

Ischemia/reperfusion leads to oxidative stress. Several endogenous enzymes are proposed to promote or prevent the effects of oxidative stress. We examined the developmental pattern for two such enzymes; calpain which is believed to have a key role in ischemic/reperfusion-induced renal tubular cell injury (9) and heme oxygenase- 1 which has been shown to ameliorate renal ischemia and reperfusion injury (10).

\section{MATERIALS AND METHODS}

Animals. Male Sprague-Dawley rats (B \& K Universal, Sollentuna, Sweden) aged 10 and $40 \mathrm{~d}$, were used in the study. 10-day-old rats developmentally correspond to an infant human kidney and 40-day-old rats, previously shown to have reached full structural maturation of the nephrons (11) correspond to an adolescent human kidney.

Preparation of primary cultured rat renal proximal tubule (RPT) cells. Rat proximal tubule cells were isolated from kidneys of 10- and 40-day-old male Sprague Dawley rats as previously described (12). Cells were cultured in supplemented DMEM $(20 \mathrm{mM}$ HEPES $/ 24 \mathrm{mM} \mathrm{NaHCO} / 3 / 10 \mu \mathrm{g} / \mathrm{mL}$ penicillin $/ 10 \mu \mathrm{g} / \mathrm{mL}$ streptomycin $/ 10 \%$ FBS) on glass coverslips or culture dishes for $48 \mathrm{~h}$ in $5 \% \mathrm{CO}_{2}$ at $37^{\circ} \mathrm{C}$.

Hypoxic chamber. The chamber was custom-made. The chamber was placed on a heater and kept at $37^{\circ} \mathrm{C}$. Ready-made mixed gas $\left(0.5 \% \mathrm{O}_{2}, 5 \% \mathrm{CO}_{2}, 94.5 \% \mathrm{~N}_{2}\right)$ was obtained from AGA Gas AB (Sweden). The gas flow was adjusted to maintain constant outflow. Normoxic cells were exposed to $20 \%$ oxygen, corresponding to $\mathrm{PO}_{2} 150 \mathrm{~mm} \mathrm{Hg}$, and hypoxic cells were exposed to $0.5 \%$ oxygen, corresponding to $\mathrm{Po}_{2} 4 \mathrm{~mm} \mathrm{Hg}$.

Ischemia-reperfusion. The abdomen was opened with a midline incision. The left renal artery was completely occluded by a nontraumatic vascular clamp for $15 \mathrm{~min}$. After release of the clamp, revascularization of the kidney was observed. Following $60 \mathrm{~min}$ of reperfusion, both kidneys were removed and the right kidney was used as a control. During the development of the mRNA technique, experiments were performed in kidneys not subjected to ischemia. The mRNA expression in these kidneys was not different from those obtained in the contralateral (right) kidney used as a control. Throughout the surgical procedure, the body temperature was maintained at $37^{\circ} \mathrm{C}$.

Immunocytochemistry. RPT cells were fixed with methanol for $9 \mathrm{~min}$ at $-20^{\circ} \mathrm{C}$. After washing with PBS, cells were incubated for $10 \mathrm{~min}$ in PBS containing 16\% normal goat serum. The cells were then incubated during overnight at $4^{\circ} \mathrm{C}$ with primary monoclonal mouse- anti- $\mathrm{Na}^{+}-\mathrm{K}^{+}$-ATPase $\alpha-1$ antibody (UPSTATE Biotechnology, NY, U.S.A.). After washing with PBS, the cells were incubated for $1 \mathrm{~h}$ at room temperature with secondary goat anti-mouse Alexa546 antibody (Molecular Probes). Negative controls used were cells incubated with secondary antibody in the absence of primary $\mathrm{Na}^{+}-\mathrm{K}^{+}$-ATPase $\alpha$-subunit antibody.

Confocal microscopy and Fluorescence quantification. The immunolabeled cells were examined using a Leica TCS SP inverted confocal scanning laser microscope using a 40/1.4 numerical aperture objective with excitation at $543 \mathrm{~nm}$ and detection at $560-650 \mathrm{~nm}$. Thin optical sections spaced $0.2 \mu \mathrm{m}$ apart were recorded throughout the cells. Gain and brightness settings were controlled to use the full dynamic range of the detectors. Optical slices taken through the center of the cells were used for the interpretation of the results. The optical sections were obtained from sites where cells revealed the strongest signal in the membrane. From each coverslip between 15 and 30 cells were analyzed.

The confocal fluorescence images were recorded and analyzed using Scion Image public domain Beta 4.0.2 (Scion Corp.). An area in the plasma membrane and an area, without nucleus, in the cytoplasm were outlined. The average of the fluorescence intensity was measured in both areas, and the membrane/cytoplasm ratio was calculated.

Ouabain sensitive ${ }^{86} \boldsymbol{R} \boldsymbol{b}^{+}$influx. ${ }^{86} \mathrm{Rb}^{+}$influx, used as an index of $\mathrm{K}^{+}$uptake, was performed as previously described (13). Briefly, RPT cells were washed twice with PBS and preincubated for $30 \mathrm{~min}$ at $37^{\circ} \mathrm{C}$ in a buffer containing (in $\mathrm{mM}$ ) $100 \mathrm{NaCl}, 4.0 \mathrm{KCl}, 1.0 \mathrm{CaCl}_{2}, 1.2 \mathrm{MgCl}_{2}, 20$ HEPES, 25 $\mathrm{NaHCO}_{3}, 1.0 \mathrm{NaH}_{2} \mathrm{PO}_{4}, 1.0 \mathrm{NaH}_{2} \mathrm{PO}_{4}, 10 \mathrm{D}$-glucose, $\mathrm{pH} 7.4$ in the presence or absence of $1 \mathrm{mM}$ ouabain. Hypoxia and reoxygenation was performed in the hypoxic chamber. $\mathrm{Na}^{+}-$ $\mathrm{K}^{+}$-ATPase -dependent ${ }^{86} \mathrm{Rb}^{+}$influx was calculated as the difference between ${ }^{86} \mathrm{Rb}^{+}$influx in the absence (total influx) and the presence (ouabain-insensitive influx) of ouabain $\left(10^{-3}\right.$ M). Protein content was determined by the method of Bradford using a kit from Bio-Rad using BSA as a standard. The rate of ${ }^{86} \mathrm{Rb}^{+}$influx was expressed in pmol $\min ^{-1} \mathrm{mg}$ protein ${ }^{-1}$.

Semiquantitative RT-PCR. Total RNA was extracted from frozen renal cortex or RPT cells using RNeasy Mini Kit (QIAGEN, Germany) and measured with a spectrophotometer (Beckman DU 640, CA, U.S.A.).

Reverse transcription was carried out in a $10 \mu \mathrm{L}$ reaction volume containing $1 \mu \mathrm{g}$ total RNA, standard M-MLV RT buffer, $0.4 \mathrm{pM}$ oligo-dT primer, $20 \mathrm{U}$ rRNasin, $80 \mathrm{U}$ M-MLV reverse transcriptase (Promega, WI, U.S.A.), $200 \mu \mathrm{M}$ dNTP (Amersham Pharmacia Biotech, UK), and incubated for $60 \mathrm{~min}$ at $42^{\circ} \mathrm{C}$. The RT reactions were terminated by inactivation at $95^{\circ} \mathrm{C}$ for $10 \mathrm{~min}$ and stored at $4^{\circ} \mathrm{C} .10 \mu \mathrm{L}$ of RT reaction were converted to a $100 \mu \mathrm{L}$ PCR mixture containing standard PCR Buffer II, 5U AmpliTaq Gold (Applied Biosystems, NJ, U.S.A.), $2.5 \mathrm{mM} \mathrm{MgCl} 2,200 \mu \mathrm{M}$ dNTP, $20 \mathrm{pM}$ specific primer pairs, internal control primer pairs and sequentially cycled for 25,30 and 35 cycles $\left(94^{\circ} \mathrm{C}\right.$ for $30 \mathrm{~s}, 60^{\circ} \mathrm{Cfor} 45$ s., $72^{\circ} \mathrm{C}$ for $60 \mathrm{~s}$ ), starting at $96^{\circ} \mathrm{C}$ for $8 \mathrm{~min}$ and finishing at $72^{\circ} \mathrm{C}$ for 5 min. To analyze $\mathrm{Na}^{+}-\mathrm{K}^{+}$-ATPase mRNA expression $20 \mu \mathrm{L}$ from each PCR reaction mixture were separated on a $1.5 \%$ agarose gel and stained with ethidium bromide. To analyze $\mu$-calpain 1 and HO- 1 mRNA expression PCR products were separated on $4.5 \%$ polyacrylamide gel. Digital images were acquired using a Fluor-S Multilmager and analyzed with original software (Quantity One, version 4.2.1, Bio-Rad Laboratories, Hercules, CA, U.S.A.). There was no interference between the specific and internal control primers (data not shown). When the reverse transcriptase was omitted from the RT reaction solution, no product appeared. All SQ RT PCR experiments were made at least three times with three different 
RNA preparations. All reaction solutions (except RNA and enzymes) were premixed to eliminate errors during pipetting. DNA molecular weight markers VI (Boehringer-Mannheim) for the polyacrylamide and GeneRuler $100 \mathrm{bp}$ DNA ladder for agarose gels were used for sizing of PCR product.

Primers for PCR (PCR). Primers were designed on the basis of their reported sequences and obtained from CyberGene, Sweden. All primers were selected from different exons to avoid amplification of genomic DNA (Table 2).

Statistics. Values are expressed as mean \pm SEM. The statistical analysis was performed with the $t$ test and with analysis of variance (ANOVA) when appropriate. $p<0.05$ was considered significant.

The study has been approved by the national ethical committee for animal experimentation.

\section{RESULTS}

The effect of hypoxia and reoxygenation on $\mathrm{Na}^{+}-\mathrm{K}^{+}$ATPase distribution was examined by immunostaining and confocal microscopy techniques in primary cultures of renal proximal tubular (RPT) cells from 10- and 40-day-old rats. $\mathrm{Na}^{+}-\mathrm{K}^{+}$-ATPase was visualized by a MAb directed toward the $\alpha$-subunit. Measurement of cellular redistribution was performed by Image software and the membrane to cytoplasm immunosignal ratio (M/C ratio) for $\mathrm{Na}^{+}-\mathrm{K}^{+}$-ATPase was calculated (Fig. 1A). A decrease in the $\mathrm{M} / \mathrm{C}$ ratio suggests a redistribution of $\mathrm{Na}^{+}-\mathrm{K}^{+}$-ATPase from the plasma membrane to cytosolic compartments. The $\mathrm{Na}^{+}-\mathrm{K}^{+}$-ATPase signal was mainly present at the plasma membrane in the normoxic $(20 \%$ $\mathrm{O}_{2}$ )RPT cells from both 10- and 40-day-old rats. After exposure to hypoxia $\left(0.5 \% \mathrm{O}_{2}\right)$ for $15-120 \mathrm{~min}$ the $\mathrm{M} / \mathrm{C}$ ratio decreased in both age groups, suggesting a redistribution of $\mathrm{Na}^{+}-\mathrm{K}^{+}$-ATPase to cytosolic compartments. In cells from 10-day-old rats the $\mathrm{M} / \mathrm{C}$ ratio decreased to a smaller extent at the 30- and 120-min time point compared with cells from 40-day-old rats (Fig. 1B). After reoxygenation of RPT cells for $30 \mathrm{~min} \mathrm{Na}^{+}-\mathrm{K}^{+}$-ATPase partially redistributed back to the plasma membrane in both mature $(80 \pm 6 \%)$ and immature (91 $\pm 4 \%$ ) cells. After $24 \mathrm{~h}$ reoxygenation a complete return to normal distribution was found in the immature cells (102 \pm $3 \%$ ) while no further recovery compared with 30 min reoxygenation was found in the mature cells $(81 \pm 3 \%$ ) (Fig. 2C).

$\mathrm{Na}^{+}-\mathrm{K}^{+}$-ATPase activity was measured as ouabain sensitive ${ }^{86} \mathrm{Rb}^{+}$influx in RPT cells (Table 1). In agreement with previous observations control $\mathrm{Na}^{+}-\mathrm{K}^{+}$-ATPase activity was significantly higher in RPT cells isolated from 40-day-old rats than 10-day-old rats (14). RPT $\mathrm{Na}^{+}-\mathrm{K}^{+}$-ATPase activity in 40-dayold rats significantly decreased after $30 \mathrm{~min}$ exposure to low oxygen $\left(0.5 \% \mathrm{O}_{2}\right)$ and returned to control values after $30 \mathrm{~min}$ reoxygenation. No significant effect was found in RPT $\mathrm{Na}^{+}-$ $\mathrm{K}^{+}$-ATPase activity in 10-day-old rats after 30 min exposure to low oxygen. Ouabain-insensitive ${ }^{86} \mathrm{Rb}^{+}$influx was not affected by hypoxia or reoxygenation.

The response of $\mathrm{Na}^{+}-\mathrm{K}^{+}$-ATPase expression to hypoxia and reoxygenation was determined by semiquantative RT-PCR techniques (Fig. 2), using $\beta$-actin as an internal control. Expression of $\mathrm{Na}^{+}-\mathrm{K}^{+}$-ATPase mRNA was significantly reduced

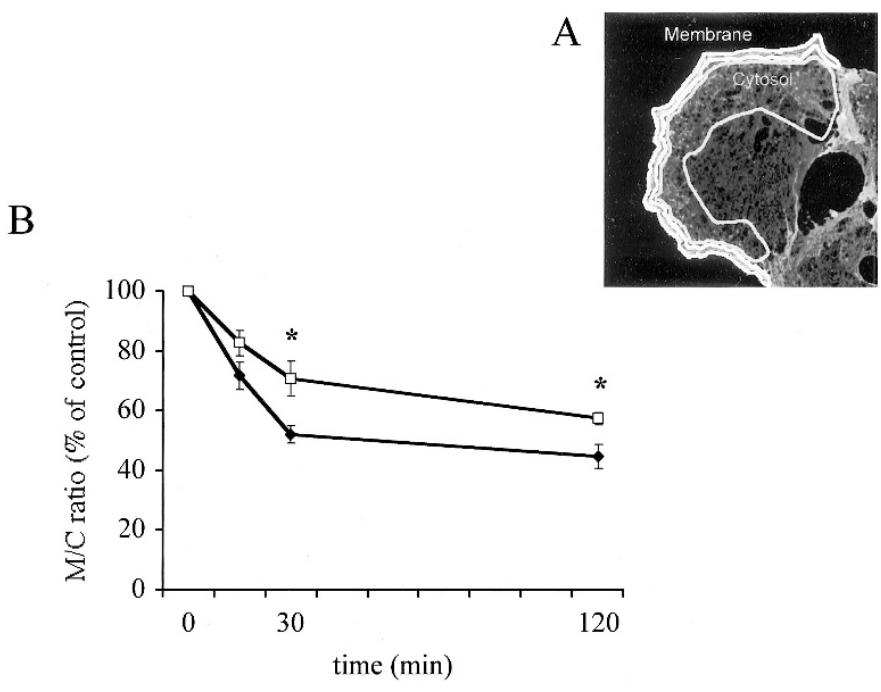

C

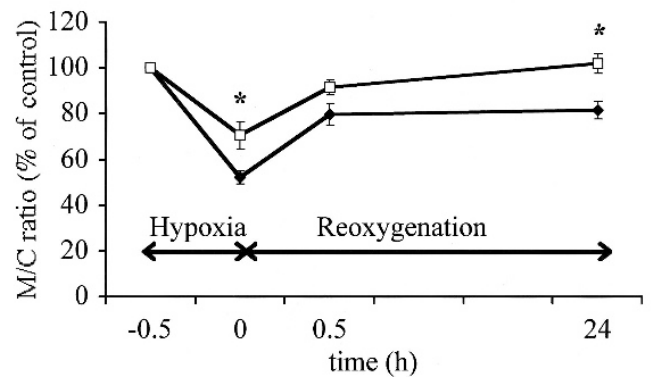

Figure 1. Semi quantitative measurements of $\mathrm{Na}^{+}-\mathrm{K}^{+}-\mathrm{ATPase}$ redistribution in primary cultures of RPT cells. $\mathrm{Na}^{+}-\mathrm{K}^{+}$-ATPase was labeled with immunohistochemistry techniques and visualized by confocal microscopy. (A) A region in the plasma membrane was selected and the $\mathrm{Na}^{+}-\mathrm{K}^{+}$-ATPase fluorescense intensity was measured. This process was repeated for an adjacent cytoplasmic area. The membrane/cytoplasm (M/C) ratio was then calculated. (B) Hypoxia 0-120 min. Unfilled squares represent RPT cells from 10-day-old rats, filled squares represent RPT cells from 40-day-old rats. (C) Hypoxia for $30 \mathrm{~min}$ followed by reoxygenation for $30 \mathrm{~min}$ and $24 \mathrm{~h}$. Unfilled squares represent RPT cells from 10-day-old rats, filled squares represent RPT cells from 40-day-old rats. The graphs show $\mathrm{Na}^{+}-\mathrm{K}^{+}$-ATPase signal $\mathrm{M} / \mathrm{C}$ ratio and represents the mean \pm SEM of at least five separate experiments. ${ }^{*} p<0.05$ vs 40-day-old rats.

in RPT cells from 40-day-old rats after 30 min of hypoxia and recovered completely to normal values after $1 \mathrm{~h}$ reoxygenation. In contrast, RPT cells from 10-day-old rats showed no change in mRNA for $\mathrm{Na}^{+}-\mathrm{K}^{+}$-ATPase in response to hypoxia.

A variety of factors are involved in the effects of ischemia/ reperfusion in renal proximal tubular cells. Some of these factors mediate the injury associated with ischemia/ reperfusion, whereas others protect the cells from such injury. We examined the developmental expression of two such factors, $\mu$-calpain and heme oxygenase-1 (HO-1) by RT-PCR techniques. RNA was extracted from frozen rat renal cortex. In studies on the effect of ischemia/reperfusion, the left renal artery was occluded by a clamp followed by reperfusion. The right unclamped kidney was used as a normoxic control. $\mu$-calpain mRNA significantly decreased in immature renal cortex compared with control value $(40 \pm 15 \%)$ after 15 min of renal ischemia followed by 60 min reperfusion. In mature 

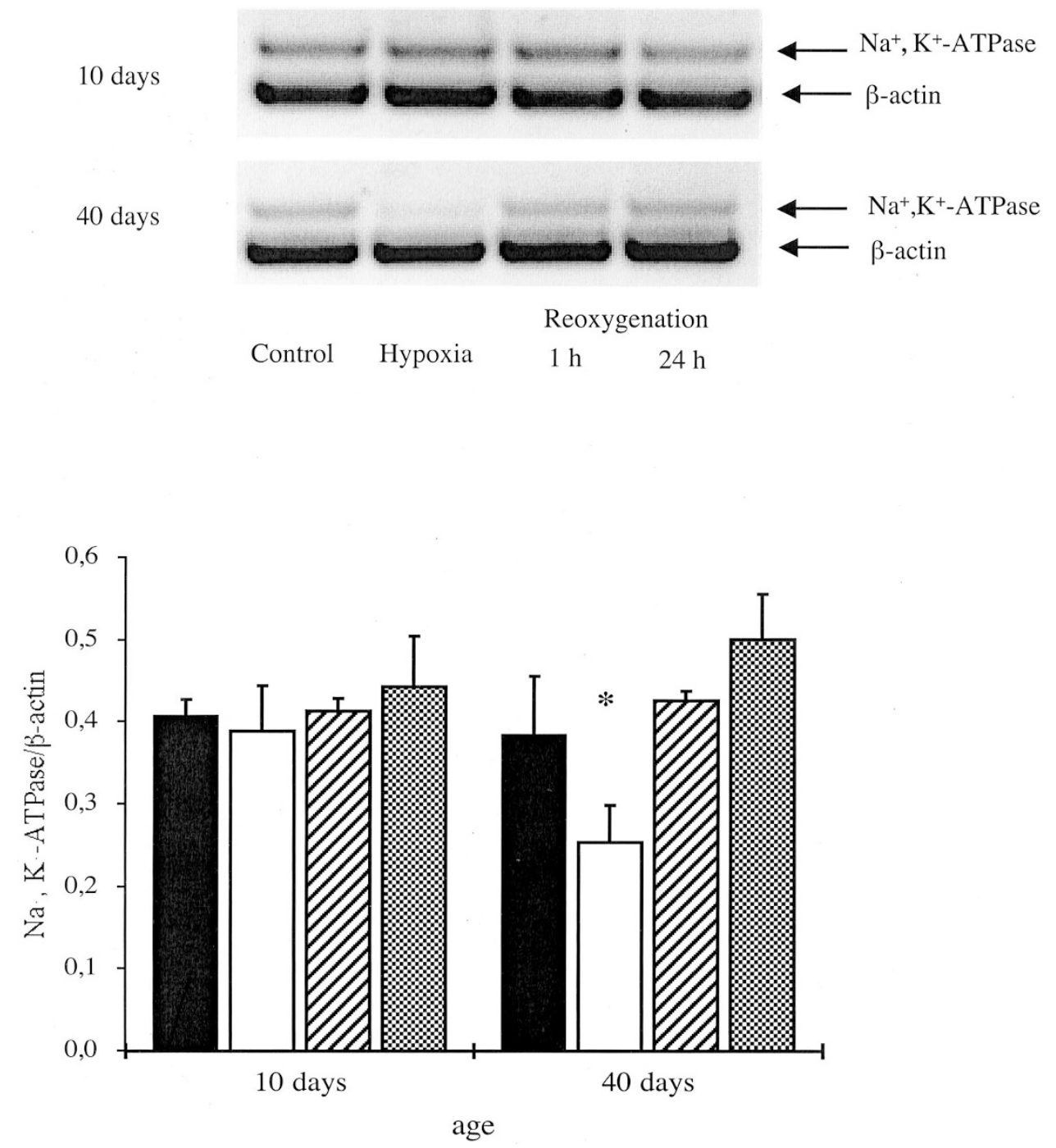

Figure 2. Expression of mRNA for $\mathrm{Na}^{+}-\mathrm{K}^{+}$-ATPase in response to hypoxia/reoxygenation. $(A)$ Representative blot of $\mathrm{Na}^{+}-\mathrm{K}^{+}-\mathrm{ATPase}$ in $\mathrm{RPT}$ cells from $10-$ and 40-day-old rats subjected to hypoxia and reoxygenation. $(B)$ Filled bars represent normoxic control, unfilled bars represent hypoxia 30 min, hatched bars represent hypoxia $30 \mathrm{~min}$ followed by reoxygenation $1 \mathrm{~h}$ and crosshatched bars represent hypoxia $30 \mathrm{~min}$ followed by reoxygenation $24 \mathrm{~h}$. Values are the ratios $\mathrm{Na}^{+}-\mathrm{K}^{+}$-ATPase $/ \beta$-actin and represent the mean \pm SEM of at least five separate experiments. ${ }^{*} p<0.05 v s$ control.

Table 1. Effect of hypoxia and reoxygenation on $\mathrm{Na}^{+}-\mathrm{K}^{+}$-ATPase activity in primary cultured RPT cells

\begin{tabular}{lccc}
\hline & Control & $\begin{array}{c}\text { Hypoxia } \\
30 \mathrm{~min}\end{array}$ & $\begin{array}{c}\text { Reoxygenation } \\
30 \mathrm{~min}\end{array}$ \\
\hline 10 day old rats & & & \\
Total Rb influx & $14.83 \pm 1.11^{*}$ & $14.69 \pm 1.68$ & $13.41 \pm 2.74$ \\
Ouabain sensitive & $6.44 \pm 0.66^{*}$ & $7.01 \pm 0.77$ & $6.69 \pm 0.91$ \\
40 day old rats & & & \\
Total Rb influx & $25.86 \pm 0.7$ & $21.24 \pm 0.73^{*}$ & $25.44 \pm 0.74$ \\
Ouabain sensitive & $18.76 \pm 0.75$ & $14.84 \pm 0.18^{*}$ & $18.22 \pm 0.64$ \\
\hline
\end{tabular}

Data are means \pm SEM and are expressed as pmol $\min ^{-1} \mathrm{mg}$ protein $^{-1}$. Ouabain sensitive $\mathrm{Rb}$ influx is calculated from total $\mathrm{Rb}$ influx-ouabain insensitive $\mathrm{Rb}$ influx, and represents the activity of $\mathrm{Na}^{+}-\mathrm{K}^{+}$-ATPase.

$* p<0.05$ vs. normoxic control RPT cells from 40-day-old rat.

renal cortex $\mu$-calpain mRNA significantly increased to $120 \pm$ $5 \%$ of the control value (Fig. 3). GADPH was used as an internal control.

HO-1 is known to ameliorate oxidative stress induced damage to the proximal tubular cell. RT-PCR showed a significant increase in mRNA for HO-1 in renal cortex from 10 day compared with renal cortex from 40-day-old rats (Fig. 4).

\section{DISCUSSION}

This study describes developmental changes of three cellular responses, all proposed to be involved in ischemia/reperfusioninduced injury to the renal tubular epithelial cells.

The proper insertion of $\mathrm{Na}^{+}-\mathrm{K}^{+}$-ATPase into the plasma membrane is essential for the reabsorptive capacity of the renal proximal tubular epithelial cells. Here we demonstrate that hypoxic immature RPT cells have a greater capacity to preserve the plasma membrane localization of $\mathrm{Na}^{+}-\mathrm{K}^{+}$-ATPase and to maintain its pump function than mature RPT cells. Furthermore, the immature kidney has a more favorable ratio between factors known to cause ischemic/reperfusion-induced cell damage and factors known to ameliorate such damage.

It is likely that these cellular responses contribute to the increased tolerance to ischemia and oxidative stress observed in the immature kidney. 
Table 2.

\begin{tabular}{|c|c|c|c|}
\hline Name & Structure of primer & $\begin{array}{c}\text { GeneBank } \\
\text { accession number }\end{array}$ & $\begin{array}{l}\text { Size of PCR } \\
\text { product }\end{array}$ \\
\hline$\mu$-calpain $U$ & CAATGCTTCTCGGGCACAATC & NM 019152 & $401 \mathrm{bp}$ \\
\hline$\mu$-calpain L & CGTCTCGATCCATGAGGTTCAC & & \\
\hline HO-1 L & GCCAACAGGAAACTGAGTGTGAGG & & \\
\hline NKA $\alpha 1 \mathrm{U}$ & ATGATTGACCCTCCTCGAGCTGCT & X04297-1 & $775 \mathrm{bp}$ \\
\hline NKA $\alpha 1 \mathrm{~L}$ & GGCCTGGATCATACCGATCTGT & & \\
\hline GAPDH U & TCCGCCCCTTCCGCTGAT & AF 106860 & $340 \mathrm{bp}$ \\
\hline GAPDH L & CACGGAAGGCCATGCCAGTGA & & \\
\hline
\end{tabular}

NKA $=\mathrm{Na}^{+}-\mathrm{K}^{+}$-ATPase

Renal ischemia causes a rapid fall in cellular ATP, followed by a disruption of the cortical actin cytoskeleton and subsequently a rapid redistribution of actin-associated $\mathrm{Na}^{+}-\mathrm{K}^{+}-$ ATPase away from the basolateral plasma membrane $(6,7)$. This redistribution of $\mathrm{Na}^{+}-\mathrm{K}^{+}$-ATPase occurs in all segments of the proximal tubules but is not observed in the distal tubules (7). Functionally, ischemia-induced redistribution of $\mathrm{Na}^{+}-\mathrm{K}^{+}-$ ATPase is in part responsible for reduced renal tubular sodium and glucose reabsorption. With recovery, proximal tubule cells undergo remodeling allowing normal cellular function to return.

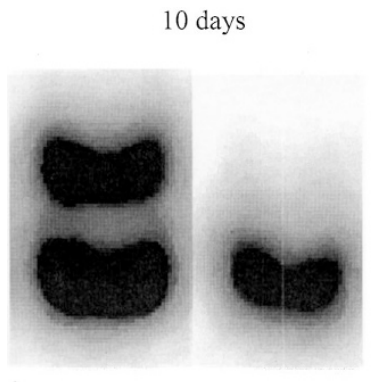

control

$\mathrm{i} / \mathrm{r}$

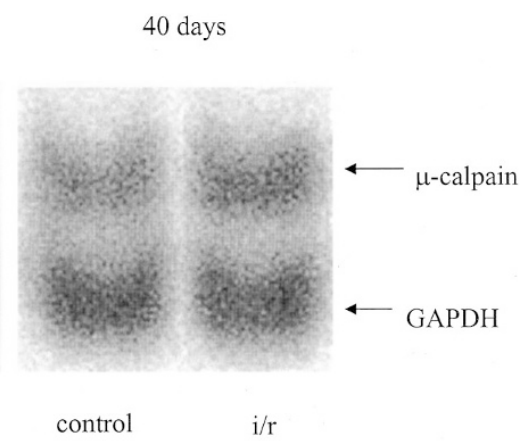

$\mathrm{i} / \mathrm{r}$

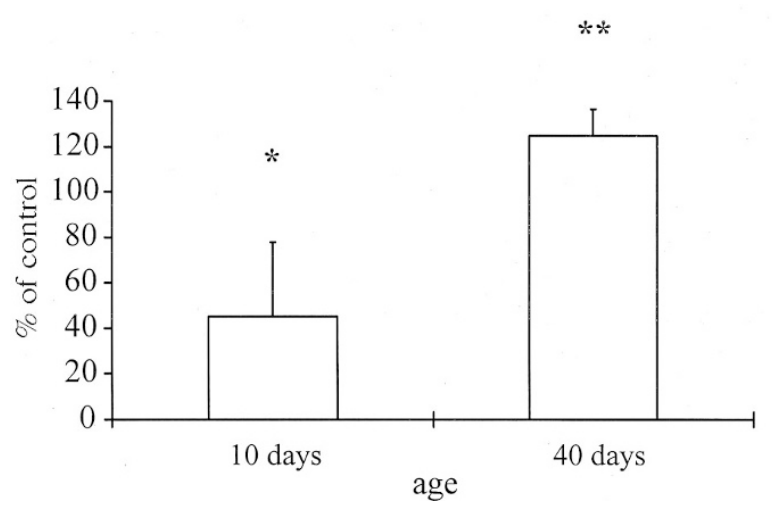

Figure 3. Expression of mRNA for $\mu$-calpain in response to ischemia/ reperfusion. $(A)$ Representative blots of $\mu$-calpain in renal cortex subjected to ischemia/reperfusion ( $\mathrm{i} / \mathrm{r})$. ( $B)$ Effect of $\mathrm{i} / \mathrm{r}$ as a percent of normoxic control; mean $\pm \mathrm{SEM}$ of at least five separate experiments. ${ }^{*} p<0.05 v s$ normoxic control kidney from 10 -day-old rats $* * p<0.05 v s$ normoxic control kidney from 40-day-old rats.
We compared $\mathrm{Na}^{+}-\mathrm{K}^{+}$-ATPase distribution in mature and immature proximal tubular cells by immunostaining and confocal microscopy techniques. $\mathrm{Na}^{+}-\mathrm{K}^{+}$-ATPase dissociated from the plasma membrane in both the mature and immature proximal tubular cell after short (15 and $30 \mathrm{~min}$ ) and prolonged (120 min) hypoxia. In comparison with immature cells, $\mathrm{Na}^{+}-$ $\mathrm{K}^{+}$-ATPase redistribution from the plasma membrane was almost 2-fold higher in mature cells during hypoxia. Durationdependent reestablishment of $\mathrm{Na}^{+}-\mathrm{K}^{+}$-ATPase in the plasma

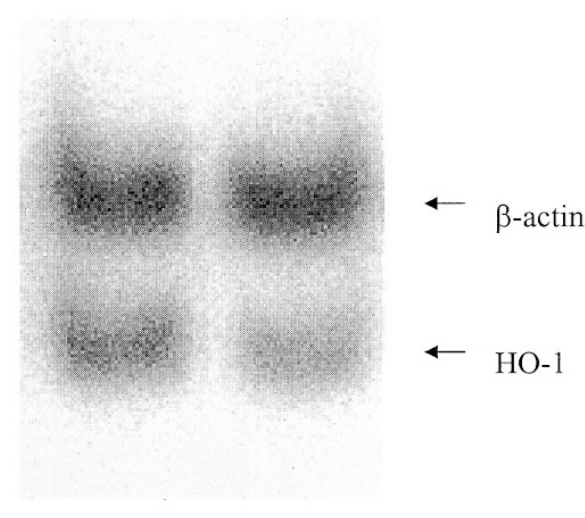

10 days $\quad 40$ days

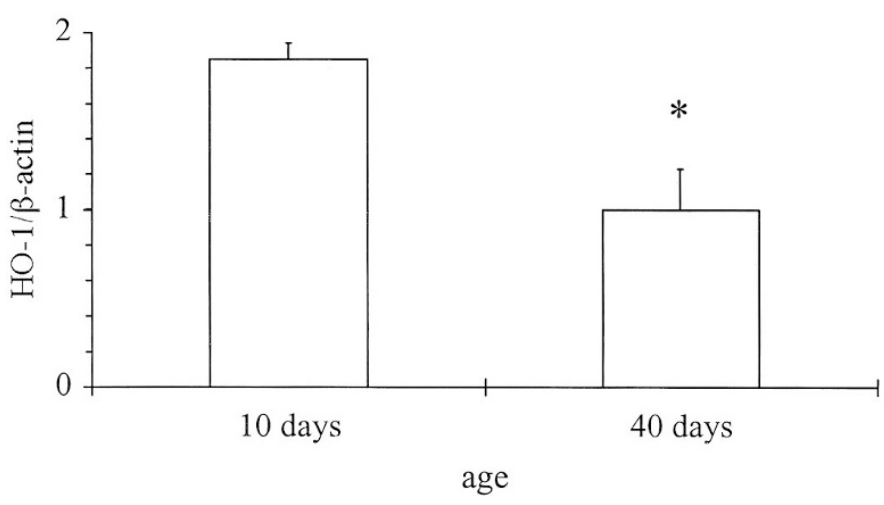

Figure 4. Expression of mRNA for heme oxygenase-1 (HO-1) in renal cortex from immature and mature rats $(A)$ Representative blots of HO-1 in renal cortex. $(B)$ Values are the ratios $\mathrm{HO}-1 / \beta$-actin and represent the mean $\pm \mathrm{SEM}$ of at least five separate experiments. ${ }^{*} p<0.05 v s$ immature renal cortex. 
membrane occurred in both mature and immature cells during reoxygenation. In contrast to the mature cell a complete recovery was observed after $24 \mathrm{~h}$ of reoxygenation in immature cells.

Hypoxia is associated with decreased activity of $\mathrm{Na}^{+}-\mathrm{K}^{+}$. ATPase and a down-regulation of its $\alpha$ and $\beta$ subunits in mature renal tubular cells $(15,16)$. The dissociation of $\mathrm{Na}^{+}-$ $\mathrm{K}^{+}$-ATPase from the plasma membrane was associated with a reduced pump function in the mature, but surprisingly not in the immature cells. This may suggest that the activity of the $\mathrm{Na}^{+}-\mathrm{K}^{+}$-ATPase that was still attached to the plasma membrane was increased in the immature cells in an attempt to compensate or that the method was not sensitive enough to detect a small decrease in its activity. Expression of $\mathrm{Na}^{+}-\mathrm{K}^{+}-$ ATPase- $\alpha$ subunit was markedly reduced in mature RPT cells after 30 min of hypoxia whereas no such down-regulation was found in the immature RPT cells.

Renal hypoxia results in an up- or down-regulation of more than 1000 genes. Some of these gene products have been shown to mediate hypoxia-induced injury whereas others have been shown to protect from such injury. Several of these factors may contribute to the tolerance of the immature tubules to hypoxia.

One enzyme suggested to have a key role in proximal tubular cell injury is calpain. Calpain is a $\mathrm{Ca}^{2+}$-dependent cytosolic cystein protease with two isoforms, $\mu$ - and mcalpain. Only the $\mu$-isoform is expressed in rat renal proximal tubules (17). Renal ishemia is known to induce disruption of the actin cytoskeleton. Calpain cleaves actin-binding proteins such as spectrin, talin, filamin, $\alpha$-actinin, and ankyrin (18). Calpain inhibition promotes the recovery of mitochondrial respiration and active $\mathrm{Na}^{+}$transport in renal proximal tubules subjected to hypoxia/reoxygenation (19). Mature renal cortex exposed to ischemia/reperfusion responded with an upregulation of calpain whereas immature renal cortex responded with a down-regulation. Whether calpain promotes dissociation and inhibition of $\mathrm{Na}^{+}-\mathrm{K}^{+}$-ATPase in mature renal tubular cells is a topic for further studies.

Heat shock factor-1 (HSF-1) is a stress responsive transcriptional factor that is activated by hypoxia and ATP depletion (20). Evidence supports a major function of heat shock proteins (HSP), the target genes of HSF, in the regulation of actin dynamics. However, in contrast to calpain, HSP is suggested to have a cytoprotective effect $(21,22)$. The hypoxic immature tubule has been demonstrated to exhibit more exuberant activation of HSF-1 and HSP-72 compared with the mature tubule, indicating a role of these factors in the tolerance of the immature tubules to hypoxia (23).

Another stress-responsive transcription factor activated by hypoxia is hypoxia-inducible factor 1 (HIF-1) (20). A target gene for HIF-1, heme oxygenase-1 (HO-1), is an enzyme shown to ameliorate renal ischemia and reperfusion injury (24). Renal tubular cells deficient of HO-1 are more susceptible to oxidative stress (25). HO-1 is an antioxidant enzyme and, in general, biochemical studies have demonstrated a developmental up-regulation of antioxidant enzymes. However, renal proximal tubules are shown to have a developmental downregulation of antioxidants such as manganese superoxide dismutase, copper, zinc superoxidase and glutathione S trans- ferase (26). We found that the expression of HO-1 was 2-fold increased in immature compared with the mature renal cortex.

\section{CONCLUSION}

In summary, these studies add further data toward the understanding of increased tolerance to stress in renal immature tubules. Renal ischemia is a common cause of acute renal failure (ARF) in adults but not in infants. One characteristic feature of ARF is a redistribution of $\mathrm{Na}^{+}-\mathrm{K}^{+}$-ATPase from the basolateral plasma membrane to the cytosol and the apical plasma membrane. Here we demonstrate that hypoxia-induced internalization of $\mathrm{Na}^{+}-\mathrm{K}^{+}$-ATPase is less pronounced in immature compare with mature renal proximal tubules. In addition, the immature kidney appears to have a higher capacity to tolerate ischemia/oxidative stress with a lower expression of cytotoxic proteins and a higher expression of cytoprotective factors.

Acknowledgments. We thank Dr. G. DiBona for guidance and support and E. Zettergren for expert technical assistance.

\section{REFERENCES}

1. Whittam R 1961 Metabolic changes in rabbit kidney cortex during the first few weeks after birth. Biochim Biophys Acta 54:574-576

2. Dicker S, Shirley D 1971 Rates of oxygen consumtion and of anaerobic glycolysis in renal cortex and medulla of adult and newborn rats and guinea pigs. J Physiol Paris 212:235-243

3. Gaudio KM, Ardito T, Kashgarian M, Siegel NJ 1994 Immature renal tubules are resistant to prolonged anoxia. Pediatr Res 35:152-154

4. Gaudio KM, Thulin G, Siegel NJ 1997 Immature tubules are tolerant of oxygene deprivation. Pediatr Nephrol 11:757-760

5. Gaudio KM, Thulin G, Siegel NJ 1996 Glycolysis is not responsible for the tolerance of immature renal tubules to anoxia. Pediatr Res 40:457-461

6. Molitoris BA, Geerdes A, McIntosh JR 1991 Dissociation and redistribution of $\mathrm{Na}^{+}-\mathrm{K}^{+}$-ATPase from its surface membrane actin cytoskeletal complex during cellular ATP depletion. J Clin Invest 88:462-469

7. Molitoris BA, Dahl R, Geerdes A 1992 Cytoskeleton disruption and apical redistribution of proximal tubule $\mathrm{Na}^{+}-\mathrm{K}^{+}$-ATPase during ischemia. Am $\mathrm{J}$ Physiol 263:F488-F495

8. Van Why SK, Kim S, Geibel J, Seebach FA, Kashgarian M, Siegel NJ 1999 Thresholds for cellular disruption and activation of the stress response in renal epithelia. Am J Physiol 277:F277-F234

9. Liu X, Rainey JJ, Harriman JF, Schnellmann RG 2001 Calpains mediate acute renal cell death: role of autolysis and translocation. Am J Physiol 281:F727F734

10. Morimoto K, Ohta K, Yachie A, Yang Y, Shimizu M, Goto C, Toma T, Kasahara Y, Yokoyama H, Miyata T, Seki H, Koizumi S 2001 Cytoprotective role of heme oxygenase (HO)-1 in human kidney with various renal disease. Kidney Int 60:18581862

11. Aperia A, Larsson L 1979 Correlation between fluid reabsorption and proximal tubule ultrastructure during development of the rat kidney. Acta Physiol Scand 105:11-22

12. Uhlén P, Laestadius Å, Jahnukainen T, Söderblom T, Bäckhed F, Celsi G, Brismar H, Normatk S, Aperia A, Richter-Dahlfors A $2000 \alpha$-hemolysin of uropathogenic E.coli induces $\mathrm{Ca}$ oscillations in renal epithelial cells. Nature 405:694-697

13. Aizman O, Uhlén P, Lal M, Brismar H, Aperia A 2001 Ouabain, a steroid hormone that signals with slow Calcium oscillations. Proc Natl Acad Sci USA 98:1342013424

14. Fryckstedt J, Svensson L-B, Lindén M, Aperia A 1993 The effect of dopamine on adenylate cyclase and $\mathrm{Na}, \mathrm{K}$-ATPase activity in the developing rat renal cortical and medullary tubule cells. Pediatr Res 34:308-311

15. Gaudio KM, Thulin G, Ardito T, Kadhgarian M, Siegel NJ 1989 Metabolic alterations in proximal tubule suspensions obtained from ischemic kidneys. Am J Physiol 257:F383-F389

16. Van Why SK, Mann AS, Ardito T, Siegel NJ, Kashgarian M 1994 Expression and molecular regulation of $\mathrm{Na}^{+}-\mathrm{K}^{+}$-ATPase after renal ischemia. Am $\mathrm{J}$ Physiol 267:F75-F85

17. Edelstein CL, Yaqoob MM, Alkhunaizi AM, Gengaro PE, Nemenoff RA, Wang KKW, Schrier RW 1996 Modulation of hypoxia-induced calpain activity in rat renal proximal tubules. Kidney Int 50:1150-1157

18. Mellgren RL 1987 Calcium dependent proteases: an enzyme system active at cell membranes? FASEB J:110-115 
19. Chatterjee PK, Brown PAJ, Cuzzocrea S, Zacharowski K, Stewart KN, Mota-Filipe H, Mcdonald MC, Thiemermann C 2001 Calpain inhibitor-1 reduces renal ischemia/ reperfusion injury in the rat. Kidney Int 59:2073-2080

20. Eickelberg O, Seebach F, Riordan M, Thulin G, Mann A, Reidy KM, Van Why SK Kashgarian M, Siegel N 2002 Functional activation of Heat shock Factor and Hypoxia-inducible factor in the kidney. J Am Soc Nephrol 13:2094-2101

21. Emami AJ, Scwartz H, Borkan SC 1992 Transient ischemia or heat stress induces a cytoppotectant protein in rat kidney. Am J Physiol 260:F479-F485

22. Van Why SK, Hildebrandt F, Ardito T, Mann AD, Siegel NJ, Kashgarian M 1992 Induction and intracellular localization of HSP-72 after renal ischemia. Am J Physiol 263:F769-F775
23. Gaudio KM, Thulin G, Mann A, Kashgarian M, Siegel NJ 1998 Role of heat stress response in the tolerance of immature renal tubules to anoxia. Am J Physiol 274:F1029-F1036

24. Horikawa S, Yoneya R, Nagashima Y, Hagiwara K, Ozasa H 2002 Prior induction of heme oxygenase-1 with glutathione depletor ameliorates the renal ischemia and reperfusion injury in rat. FEBS Lett 510:221-224

25. Yachie A, Niida Y, Wada T, Igarashi N, Kaneda H, Toma T, Ohta K, Kasahara Y, Koizumo S 1999 Oxidative stress causes enhanced endothelial cell injury in human heme oxygenase-1 deficiency. J Clin Invest 103:129-135

26. Oberley TD, Sempf JM, Oberley LW 1995 Immunohistochemical localization of antioxidant enzymes during hamster kidney development. Histochem J 27:575-586 